\title{
Timing of reproduction in Montastraea annularis: relationship to environmental variables
}

\author{
J. M. Mendes*, J. D. Woodley \\ Department of Life Sciences, University of the West Indies, Mona, Kingston 7, Jamaica
}

\begin{abstract}
The timing of reproduction was investigated in 15 colonies of Montastraea annularis located on the Port Royal Cays, Jamaica. Spawning occurred between Days 6 and 8 after August's and/or September's full moon. In the $14 \mathrm{wk}$ prior to spawning, mean total gonad size increased from $0.30 \pm 0.17$ to $34.38 \pm 13.20 \%$ of the polyp cross-sectional area. Gonad size was significantly correlated with temperature and light intensity, but was not correlated with photoperiod or rainfall. Spawning occurred in the month prior to the period of heaviest rainfall, when temperatures were at their maximum. A meta-analysis of spawning time and climatic conditions at 19 other geographical locations also showed that spawning occurs in those periods without heavy rainfall in which temperatures are warmest. The data presented here suggest that temperature is not the only environmental variable controlling the annual timing of coral spawning. Rather, the time of coral spawning is controlled by a combination of temperature and rainfall.
\end{abstract}

KEY WORDS: Montastraea annularis - Coral · Reproduction · Spawning · Environmental cues · Rainfall

\section{INTRODUCTION}

Broadcast spawning coral species often participate in synchronized mass spawning events, i.e. simultaneous spawning by many species over a few nights (Harrison et al. 1984). Synchronized mass spawning has the advantages of increasing the chances of fertilization, cross-fertilization and genetic mixing between colonies (with fertilization taking place at the 2-dimensional ocean surface), and of reducing overall predation (by predator satiation; Oliver et al. 1988). The disadvantages of synchronized spawning include the possible formation of non-viable, inter-species hybrids during the period of fertilization (Willis et al. 1985, Oliver et al. 1988), exposure of all gametes to adverse weather conditions at the surface, and transportation of gametes and larvae from their reef of origin by strong surface currents (Veron 1995, Wolanski \& Sarsenski 1997).

\footnotetext{
*E-mail: jmendes@uwimona.edu.jm
}

The timing of annual coral spawning events varies geographically (with spawning events reported in every month of the year at different locations around the world; Table 1) but is consistent and predictable at any particular location (Harrison \& Wallace 1990). However, spawning may not even be annual, and is not always as synchronized as the Australian spawning events which were the first to be reported (Harrison et al. 1984, Babcock et al. 1986). For example, in Japan synchronous multispecies spawnings occur over several months from May until September (Heyward et al. 1987), while in Hawaii and the Red Sea many species have separate spawning times staggered throughout the summer (Hodgson 1985, Schlesinger \& Loya 1985, Heyward 1986). Corals which deviate from annual periodicity include several species in Papua New Guinea that show evidence of bi-annual spawning, with 2 gametogenic cycles a year (Oliver et al. 1988). Bi-annual spawning has also been found in 3 species of Montipora at Magnetic Island on the Great Barrier Reef, in which the first spawning occurs in October and the second in March (Stobart et al. 1992). 
Table 1. Timing of coral spawning events in different geographical locations

\begin{tabular}{|c|c|c|c|}
\hline Location & $\begin{array}{l}\text { Month of pre- } \\
\text { spawning full moon }\end{array}$ & $\begin{array}{l}\text { Nights after } \\
\text { full moon }\end{array}$ & Source \\
\hline Lord Howe Island, South East Australia & Jan & & Harrison (2000) \\
\hline Western Australia & Feb, Mar, Apr & $4-11$ & $\begin{array}{l}\text { Simpson (1985), Simpson et al. (1993), } \\
\text { Babcock et al. (1994) }\end{array}$ \\
\hline $\begin{array}{l}\text { Great Barrier Reef, Australia (18.3 to } 19.1^{\circ} \mathrm{S} \\
\text { (3 Montipora and } 4 \text { Turbinaria species only) }\end{array}$ & Mar, Apr, May & $1-4$ & $\begin{array}{l}\text { Harrison et al. (1984), Stobart et al. (1992), } \\
\text { Willis et al. (1985) }\end{array}$ \\
\hline Maldives & Mar & & Sier \& Olive (1994) \\
\hline Southern Taiwan & Apr, May & $1-9$ & Dai et al. (1992) \\
\hline Palau & May, Jun & $4-7$ & Kenyon (1995) \\
\hline Northern Taiwan & May, Jun & & Dai et al. (1992) \\
\hline Okinawa, Japan & May, Jun, Jul, Aug, Sep & $2-8$ & $\begin{array}{l}\text { Heyward et al. (1987), Hayashibara et al. } \\
\text { (1993), Sakai (1997) }\end{array}$ \\
\hline Red Sea & May, Jun, Jul, Aug, Sep & $1-7$ & $\begin{array}{l}\text { Rickevich \& Loya (1979), Schlesinger \& } \\
\text { Loya (1985) }\end{array}$ \\
\hline Yap & Jun & $4-8$ & Kenyon (1995) \\
\hline Hawaii & Jun, Jul, Aug & $1-8$ & Heyward (1986), Richmond \& Hunter (1990) \\
\hline Guam & Jun, Jul & $5-10$ & Heyward (1989), Richmond \& Hunter (1990) \\
\hline $\begin{array}{l}\text { Northern Taiwan } \\
\text { (Echinopora lamellosa only) }\end{array}$ & Jul, Aug & & Fan \& Dai (1995) \\
\hline Bermuda & Jul, Aug & $6-9$ & Wyers (1985), Wyers et al. (1991) \\
\hline Puerto Rico & Aug & $6-9$ & Steiner (1995) \\
\hline Gulf of Mexico, Texas Flower Gardens & Jul, Aug & $7-8$ & Gittings et al. (1992) \\
\hline Florida Keys & Aug, Sep & $6-8$ & Szmant et al. (1997) \\
\hline Curacao & Aug, Sep, Oct & $6-8$ & van Veghel (1994), van Veghel \& Bak (1994) \\
\hline $\begin{array}{l}\text { Southern Taiwan } \\
\text { (Echinopora lamellosa only) }\end{array}$ & Sep, Oct & & Dai et al. (1992), Fan \& Dai (1995) \\
\hline Great Barrier Reef, Australia (14.5 to $23.5^{\circ} \mathrm{S}$ & Oct, Nov & $1-8$ & $\begin{array}{l}\text { Harrison et al. (1984), Willis et al. (1985), } \\
\text { Babcock et al. 1986, Oliver et al. (1988) }\end{array}$ \\
\hline Solomon Islands & Nov & $3-5$ & Baird et al. (2001) \\
\hline
\end{tabular}

The timing of spawning has, from the earliest reports on the Great Barrier Reef (Harrison et al. 1984, Babcock et al. 1986), been interpreted with respect to the 3 principal determinants of reproduction time known for other marine invertebrates: annual temperature variation, lunar cycles, and the diurnal light cycle (Korringa 1947, Giese \& Pearse 1974). Babcock et al. (1986) found that on the Great Barrier Reef these spawning-control factors operate at successively finer time scales, with sea temperature controlling the time of year, monthly lunar or tidal cycles controlling the time of month, and diurnal light cycles controlling the hour of spawning. Oliver et al. (1988) considered these factors to be proximate (i.e. they provide reliable timing signals to synchronize spawning) rather than ultimate (i.e. selective pressures responsible for the evolution and persistence of the spawning phenomena). According to Oliver et al. (1988), the ultimate factor underlying the timing signal of water temperature (spawning on the Great Barrier Reef occurred during periods of increasing water temperature) is sufficient time for the maturation of gonads. The ultimate factor underlying the lunar or tidal cycles (spawning occurred at low amplitude neap tides) is the increased possibility of fertilization at a period of low water motion and low water volume. The ultimate factor underlying diurnal light cycles (spawning occurred after sunset, during the week after full moon when the moon is rising later at night) is reduction in the exposure of the gametes to predators.

While coral spawning, at any geographical location, never occurs at the low end of the annual temperature range, the relationship between spawning and environmental temperature is inconsistent. For example, a study by Simpson (1985) concluded that seasonal changes in sea temperature do not control coral spawning because the timing of gametogenesis and spawning differs between populations of the same species on the east and west coast of Australia (spawning in spring and autumn, respectively), despite the fact that they experience similar seasonal temperature patterns. Additionally, in Japan spawning occurs not only during periods of rising temperatures, but also during periods of maximum and declining water temperature (Hayashibara et al. 1993, Sakai 1997). There are even exceptions to the predominant annual spawning pattern on the Great Barrier Reef. For example, 4 species of Turbinaria on Heron Island have been found to spawn in autumn (when temperatures are decreasing) not spring (Harrison et al. 1984, Willis et al. 1985), and 3 species of Montipora spawn bi-annually, in spring and autumn, at Magnetic Island (Stobart et al. 1992). The inconsistency in the relationship between temper- 
ature and coral spawning raises the possibility that an environmental variable other than or in addition to temperature may exist as a controlling factor for the timing of annual spawning events.

One seldomly examined environmental factor that might account for the variation in annual timing of spawning events in different parts of the world is rainfall. Rainfall decreases salinity, particularly at the surface, so that gametes might be released into a surface layer of lowered salinity. Laboratory experiments designed to test the effects of salinity on fertilization and larval development in corals have found an $86 \%$ decrease in fertilization rate with a $20 \%$ decrease in salinity (from 35 to $28 \%$; Richmond 1993). With the addition of sediment to the water (as might be found in river run off after rainfall), a mere $6 \%$ drop in salinity was all that was needed to cause an $86 \%$ decrease in fertilization rate (Richmond 1993). Rainfall at the time of spawning could thus greatly reduce reproductive success, an important condition for any environmental variable to exert selection pressure, and therefore serve as an ultimate factor. For example, in November 1981, all coral gametes and larvae on the water surface at Magnetic Island were destroyed by heavy rainfall (Harrison et al. 1984). Laboratory experiments have also shown that lowered salinity decreased larval survival and the settlement rate of planulae in corals (Richmond 1993, 1996).

The first aim of the present study (the first to document coral spawning in Jamaica) was to investigate gonad maturation and spawning in Montastraea annularis (a hermaphroditic, broadcast spawning coral species, with an annual protogynous gametogenic cycle that lasts approximately 20 wk; Szmant 1986, 1991) in relation to the traditional environmental factors of temperature and light, as well as to the less examined factor of rainfall. Secondly, we compared the relationship between spawning time and climatic conditions in Jamaica with those found at other geographical locations by meta-analysis of published accounts of spawning time at 19 other locations.

\section{MATERIALS AND METHODS}

Study site and sampling methods. This study was conducted at 2 reef locations (Drunkenmans Cay and South East Cay) within the Port Royal Cays (Fig. 1), a collection of 8 small coral islets on Jamaica's southern shelf, adjacent to the capital city of Kingston.

Fifteen large (approximately 0.5 to $2 \mathrm{~m}^{2}$ ) columnar colonies of Montastraea annularis located at a depth of approximately $5 \mathrm{~m}$ on the Port Royal Cays (10 at Drunkenmans Cay, 5 at South East Cay; Fig. 1) were sampled repeatedly over the period from October 1994

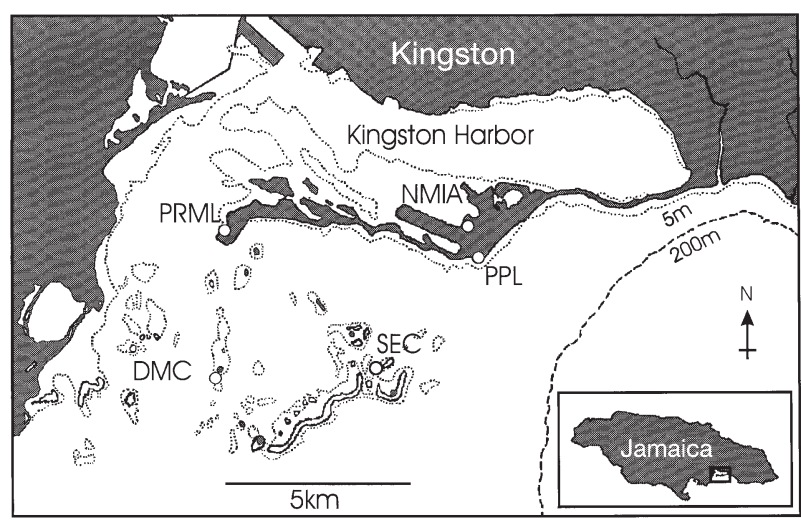

Fig. 1. Location of study sites. DMC = Drunkenmans Cay site, $\mathrm{SEC}=$ South East Cay site, $\mathrm{PRML}=$ Port Royal Marine Laboratory, NMIA = Norman Manley International Airport, PPL = Plumb Point Lighthouse

to September 1997. A $4 \mathrm{~cm}$ diameter hole saw, powered by a pneumatic drill, was used to collect short (3 to $5 \mathrm{~cm}$ ) cores of skeleton and tissue from the tops of coral columns within each colony. Five colonies were sampled at every full and new moon (i.e. approx. every 2 wk) from October 1994 until December 1995. The remaining 10 colonies were sampled at every full moon (i.e. approximately once a month) from April 1995 until March 1996. Samples were then taken for all colonies either monthly or bi-monthly until October 1996, and then at 1 to 6 mo intervals until September 1997. The samples were fixed with $10 \%$ seawater formalin for $24 \mathrm{~h}$ and rinsed in running tap water for approximately $6 \mathrm{~h}$. Cores were cut longitudinally into two with a rock saw (Contempo Lapidary, Sylmar, CA).

Gametogenesis and fecundity. The portion of each core sample to be used in histological studies of reproductive structures was decalcified in $10 \% \mathrm{HCl}$. The soft tissue remaining after decalcification was then washed overnight in running tap water to remove the acid and stored in $70 \%$ ethanol (with $1 \%$ glycerol) until it was embedded. For each sample, tissue containing 10 to 20 polyps was dehydrated, cleared, and embedded in paraffin. Then serial cross-sections, $8 \mu \mathrm{m}$ thick, were cut from 5 different levels within the polyps and mounted on glass slides. Slides were stained with Heidenhain's azocarmine-aniline blue (Luna 1968) and examined with a compound microscope at $400 \times$. The developmental stage of any observed gametocytes was scored according to criteria in Szmant-Froelich et al. (1980).

For each sample, the slide with polyps containing the greatest expression of gonads (lower mid-section of the polyp) was used to estimate coral fecundity (gonad number and size; Guzman \& Holtz 1993). The size (cross-sectional area) of 5 randomly chosen polyps and 
the size of their gonads were measured. Images of the polyps were generated with a microscope-mounted video camera (Teachcam w/ illumabase NTSC Rev 6.5, Video Labs, Golden Valley, MN) and captured using a video digitizer (Snappy video snapshot v3.0, Play, Rancho Cordova, CA). Measurements were made on captured images using SigmaScan Pro automated image analysis software (SPSS, San Rafael, CA).

Spawning observations. Nocturnal monitoring was conducted on the Port Royal Cays on potential Montastraea annularis spawning nights (based on reports of spawning in the Caribbean; Van Veghel 1994, Szmant 1991), after the full moon in August 1994, September 1995, and August and September 1996 and 1997. In 1995 and 1997, an underwater trail that connected the 10 sample colonies of Montastraea annularis on Drunkenmans Cay (Fig. 1) was set up. On each monitoring night, observations were made continuously from 18:00 until 00:00 $\mathrm{h}$ or until spawning ceased. The times of first and last gamete bundle release at the site were recorded, as well as the occurrence of spawning activity in the sample colonies.

Environmental variables. Water temperature was recorded, at $5 \mathrm{~m}$ depth, from April 1995 to December 1996 at Drunkenmans Cay in the Port Royal Cays (Fig. 1) using HOBOtemp miniature data loggers with internal sensors (Onset Computer Corporation, Pocasset, MA). The data loggers were deployed in opaque waterproof cases and further protected in plastic housings with holes at the side to permit water movement. This arrangement prevented light/radiant energy from heating the air space around the data loggers (which leads to erroneous readings; A. Szmant pers. comm.). Calibration accuracy of the sensors was tested by checking the temperature at $0^{\circ} \mathrm{C}$ with an ice bath. All sensors read within \pm 0.12 at $0^{\circ} \mathrm{C}$. Light intensity and photoperiod were recorded at the site from April 1995 to March 1996 using HOBOLi miniature data loggers (Onset Computer Corporation, Pocasset, MA). Daily rainfall and temperature data, for the period January 1995 to December 1996, were obtained from the National Meteorological Service station closest to the study site (The Norman Manley International Airport, $3.5 \mathrm{~km}$ north of the study site; Fig. 1).

Climate data (mean monthly rainfall and air temperature) used in the meta-analysis of spawning observations were obtained from the Global Historical Climate Network and the National Climatic Data Centre Cooperative station databases (see Fig. 4 for the exact locations of and number of years in the utilized data sets).

Statistical analysis. All data were first tested for normality by the Shapiro-Wilk $W$ statistic and by examination of normal probability plots. Violation of the normality assumption was found in the gonad size data. Consequently mean monthly gonad size was corre- lated with total monthly rainfall, mean monthly water temperature, photoperiod, and light intensity using the non-parametric Gamma statistic (this is preferable to Spearman R or Kendall tau when the data contains many tied observations).

When comparing time of spawning at all sites worldwide, the temperature data were coded to remove differences in absolute temperatures caused by variation in latitude. Temperature for each month at each site was calculated as a proportion (\%) of the annual temperature range at that site and then assigned to 1 of 5 distinct categories $(0-20,21-40,41-60,61-80$ and $81-100 \%$ of the temperature range). Total monthly rainfall values were similarly divided into 5 categories, using the highest observed total monthly rainfall (475 mm; September in Northern Taiwan) as the maximum value for the category range; each category represented $20 \%$ of this maximum $(0-95,96-190$, 191-285, 286-380 and 381-475 mm). These categorized data on temperature, rainfall and month of prespawning full moons were cross-tabulated and the resulting multi-way frequency table examined by loglinear analysis. All statistical analyses were performed with STATISTICA (V.6, 1998), using a significance level of $p<0.05$. All data are presented as means \pm SE.

\section{RESULTS}

\section{Gametogenesis and spawning}

In 1995, gonads (consisting of stage II oocytes) were first observed in sections of material fixed in early June, 14 wk before spawning; at this time the mean gonad size was $15.77 \pm 6.75 \mu^{2}$, and gonads occupied $0.80 \pm 0.19 \%$ of the polyp cross-sectional area. Spermaries (stage II) were not observed until early August, 5 wk before spawning. One wk prior to spawning, the gonads contained full-size oocytes (Stage IV, with vitelline membranes) and spermaries (Stage V, spermatozoa with tails), mean gonad size was $535.01 \pm$ $40.67 \mathrm{~m}^{2}$, and the gonads occupied $34.38 \pm 3.40 \%$ of the polyp cross-sectional area (Fig. 2a). After spawning, unspawned gametes were present in the tissues for up to $3 \mathrm{wk}$ before being reabsorbed by the polyp. Unspawned gametes (at $7 \mathrm{~d}$ post-spawning) occupied $2.70 \pm 0.80 \%$ of the polyp cross-sectional area.

Spawning occurred over 1 or $2 \mathrm{~d}$, between Days 6 and 8 after the full moon in August or September or both (Table 2). However, no full moon in the first 3 weeks of August was followed by spawning, but all 5 full moons from late August to the end of September (during the period 1994-1997) preceded spawning. In 1996, a split spawning event, in which gamete bundles are released in 2 consecutive months, was observed. In 

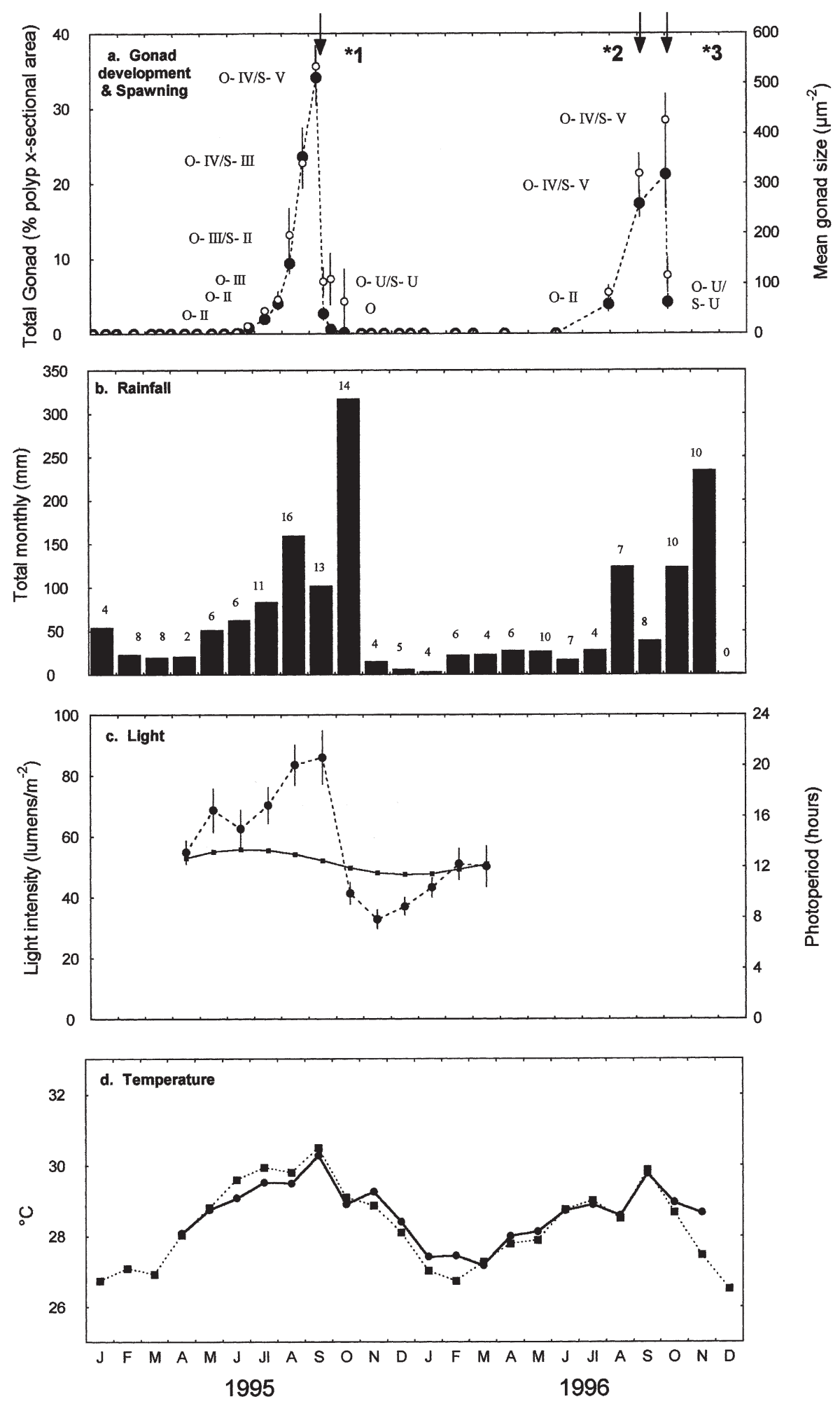

Fig. 2. Relationships of gonad development and time of spawning to environmental parameters in Montastraea annularis. (a) $\downarrow=$ spawning events. ${ }^{*} \mathbf{1}=15$ and 16 September $1995 ;{ }^{*} \mathbf{2}=4$ September $1996 ;{ }^{*} \mathbf{3}=3$ and 4 October $1996 . \cdots \bullet \cdots=$ total gonad as a $\%$ of polyp cross-sectional area; $\mathrm{O}=$ mean gonad size (oocyte and spermary combined; $\mu^{2}{ }^{2}$ ). O-/S- = highest stage of gonad development observed. (b) Numbers = number of rain days. (c) $-\mathbf{-}=$ photoperiod; $\cdots \cdot \cdots=$ mean light intensity per daylight hour. (d) $-\boldsymbol{-}=$ mean monthly water temperature at $5 \mathrm{~m}$ depth (Drunkenmans Cay); $\cdots \cdots=$ mean monthly air temperature (Norman Manley International Airport) 


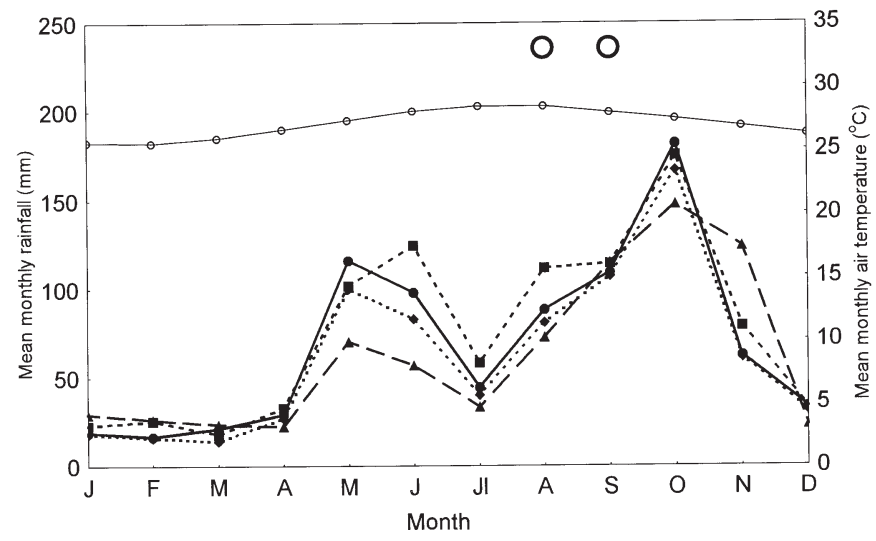

Fig. 3. Mean monthly rainfall, Kingston, Jamaica. - - 1870 to $1929 ; \ldots$... 1931 to $1960 ; \ldots \star \cdots 1951$ to $1980 ; \ldots \mathbf{\Delta} \cdots 1992$ to 2000 Data for 1870 to 1929 is for Plumb Point lighthouse (Fig. 2; Jamaica Meteorological Office 1943); Data for 1931 to 1960 is for Plumb Point lighthouse (Jamaica Meteorological Service 1973); Data for 1951 to 1980 and 1992 to 2000 provided by the National Meteorological Service, Norman Manley International Airport (Fig. 2). $--=$ mean monthly temperature (data for Kingston, 1852 to 1992; Global Historical Climate Network database, version 1). $\bigcirc=$ pre-spawning full moons (present study)

1996, the full moon occurred very late in August (28), so that spawning actually took place in early September, then again in early October. Analysis of gonad development in 1996 indicated that only 2 of the sample colonies (i.e. $13 \%$ ) spawned after the August full moon, while 11 of the remaining 13 colonies spawned after the September full moon (2 colonies did not spawn at all in 1996). Mean individual gonad size prior to the predicted spawning time, following the August full moon, was significantly larger for the 2 colonies that spawned after the August full moon than for the other colonies that spawned $\left(508.41 \pm 66.82 \mu \mathrm{m}^{2}\right.$ com- pared with $351.22 \pm 38.77{\mu \mathrm{m}^{2}}^{2} t=2.52, \mathrm{df}=11, \mathrm{p}<$ $0.05)$. In each of the 3 years that spawning observations were made, spawning began between 3 and $4 \mathrm{~h}$ after sunset, while spawning duration ranged from 20 to $52 \mathrm{~min}$.

\section{Relationship of reproduction to environmental variables}

The trends in temperature, light and rainfall for 1995 and 1996, as well as gonad size and time of spawning, are shown in Fig. 2. Gonad size is significantly correlated with temperature $(\gamma=0.70, \mathrm{p}<0.05, \mathrm{n}=24)$ and light intensity $(\gamma=0.83, \mathrm{p}<0.05, \mathrm{n}=24)$, but is not correlated with photoperiod $(\gamma=0.31, \mathrm{p}=0.13, \mathrm{n}=24)$ or total monthly rainfall $(\gamma=0.34, p=0.12, n=24)$. Spawning occurred most frequently after the September full moon, in the month prior to the period of heaviest rainfall, when temperatures were at their maximum. The same pattern is found when the timing of spawning is compared with the long-term rainfall and air temperature data for the area (Fig. 3).

\section{Relationship of spawning to environmental variables at all geographical locations}

The relationships between temperature, rainfall and spawning at all 19 sites listed in Table 1, are shown in Fig. 4. Fig. 4 shows that the absolute temperature at which spawning takes place varies considerably (from approximately 23 to $32^{\circ} \mathrm{C}$ ). Spawning, however, occurs at all sites during the warmer half of the annual temperature range. At 16 of the 19 sites this includes spawning at the maximum temperature. The 3 exceptions are Southern Taiwan (Fig. 4g), the Great Barrier

Fig. 4. Timing of spawning in relation to temperature and rainfall at different geographical locations. Graphs arranged in order of decreasing temperature range; solid bars = rainfall; lines $=$ temperature $; O=$ pre-spawning full moons. Graphs covering more than 1 location: (e) - - and black bar $=$ Carnarvon, $\cdots \circ \cdots$ and striped bar $=$ Geraldton; $(\mathrm{s})-\bullet-$ and black bar $=$ Cairns, $\cdots \circ \cdots$ and striped bar = MacKay. Data sources (GHCN1 = Global Historical Climate Network database, version 1, 1992; GHCN2 beta = Global Historical Climate Network database, version 2 beta, 1992; NCDC = National Climate Date Co-operative stations database). (a) Eilat, Israel $\left(29.55^{\circ} \mathrm{N}, 34.98^{\circ} \mathrm{E}\right.$; temperature data year range, $t=1951$ to 1990$)$ and Ma-an, Jordan $\left(30.17^{\circ} \mathrm{N}, 35.70^{\circ} \mathrm{E}\right.$; rainfall data year range, $r=1961$ to 1990$)$; (b) Corpus Christi $\left(27.76^{\circ} \mathrm{N}, 97.50^{\circ} \mathrm{W} ; t\right.$ and $r=1900$ to 1995$)$; (c) Yilan $\left(24.77^{\circ} \mathrm{N}, 121.70^{\circ} \mathrm{E}_{;} t=1981\right.$ to $1990 ; r=$ 1951 to 1990$)$; (d) Naha $\left(26.20^{\circ} \mathrm{N}, 127.70^{\circ} \mathrm{N} ; t=1891\right.$ to $1991 ; r=1952$ to 1972$)$; (e) Carnarvon $\left(24.87^{\circ} \mathrm{S}, 113.60^{\circ} \mathrm{E} ; t=1951\right.$ to 1990 ;

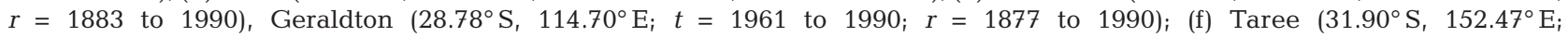
$t=1862$ to $1992 ; r=1862$ to 1989$) ;(\mathrm{g})$ Kao Husing $\left(22.57^{\circ} \mathrm{N}, 130.30^{\circ} \mathrm{E} ; t=1981\right.$ to $1990 ; r=1951$ to 1990$) ;(\mathrm{h})$ Bermuda NAS $\left(32.36^{\circ} \mathrm{N}, 64.59^{\circ} \mathrm{W} ; t=1931\right.$ to $1990 ; r=1856$ to 1990$) ;\left(\right.$ i) Cairns $\left(16.88^{\circ} \mathrm{S}, 145.75^{\circ} \mathrm{E} ; t=1907\right.$ to $1992 ; r=1882$ to 1989$), \mathrm{MacKay}$ $\left(21.12^{\circ} \mathrm{S}, 149.19^{\circ} \mathrm{E}_{i} t=1951\right.$ to $1990 ; r=1951$ to 1991$) ;(\mathrm{j})$ Townsville $\left(19.25^{\circ} \mathrm{S}, 146.69^{\circ} \mathrm{E} ; t=1940\right.$ to $1990 ; r=1951$ to 1990$)$; (k) Tavernier $\left(25.00^{\circ} \mathrm{N}, 80.51^{\circ} \mathrm{W} ; t=1961\right.$ to $1990 ; r=1936$ to 1995$) ;(\mathrm{l})$ Kaneohe Bay $\left(21.35^{\circ} \mathrm{N}, 157.90^{\circ} \mathrm{W} ; r=1941\right.$ to 1949$)$ and Honolulu $\left(21.35^{\circ} \mathrm{N}, 175.93^{\circ} \mathrm{W} ; t=1883\right.$ to 1994$) ;(\mathrm{m})$ Magueyes Island $\left(17.96^{\circ} \mathrm{N}, 67.05^{\circ} \mathrm{W} ; t=1961\right.$ to $1990 ; r=1959$ to 1995$)$; (n) Kingston $\left(17.93^{\circ} \mathrm{N}, 76.70^{\circ} \mathrm{W} ; t\right.$ and $r=1852$ to 1990$) ;$ (o) Hato International Airport $\left(12.20^{\circ} \mathrm{N}, 68.90^{\circ} \mathrm{W} ; t\right.$ and $r=1951$ to 1990$)$; (p) Minicoy $\left(8.30^{\circ} \mathrm{N}, 73.09^{\circ} \mathrm{E} ; t=1941\right.$ to $1990 ; r=1891$ to 1990$) ;(\mathrm{q})$ Agana $\left(13.48^{\circ} \mathrm{N}, 144.80^{\circ} \mathrm{E} ; \mathrm{t}=1921\right.$ to 1987$)$ and Mangilao $\left(13.45^{\circ} \mathrm{N}, 144.81^{\circ} \mathrm{E} ; r=1970\right.$ to 1995$)$; (r) Honiara $\left(9.42^{\circ} \mathrm{S}, 160.00^{\circ} \mathrm{E} ; t=1951\right.$ to 1990$)$ and Tulagi $\left(9.10^{\circ} \mathrm{S}, 160.10^{\circ} \mathrm{E} ; r=1909\right.$ to $1941) ;(\mathrm{s}) \operatorname{Yap}\left(9.48^{\circ} \mathrm{N}, 138.00^{\circ} \mathrm{E} ; t=1921\right.$ to $1990 ; r=1900$ to 1989$) ;(\mathrm{t})$ Koror $\left(7.33^{\circ} \mathrm{N}, 134.40^{\circ} \mathrm{E} ; t\right.$ and $r=1924$ to 1990$)$ 

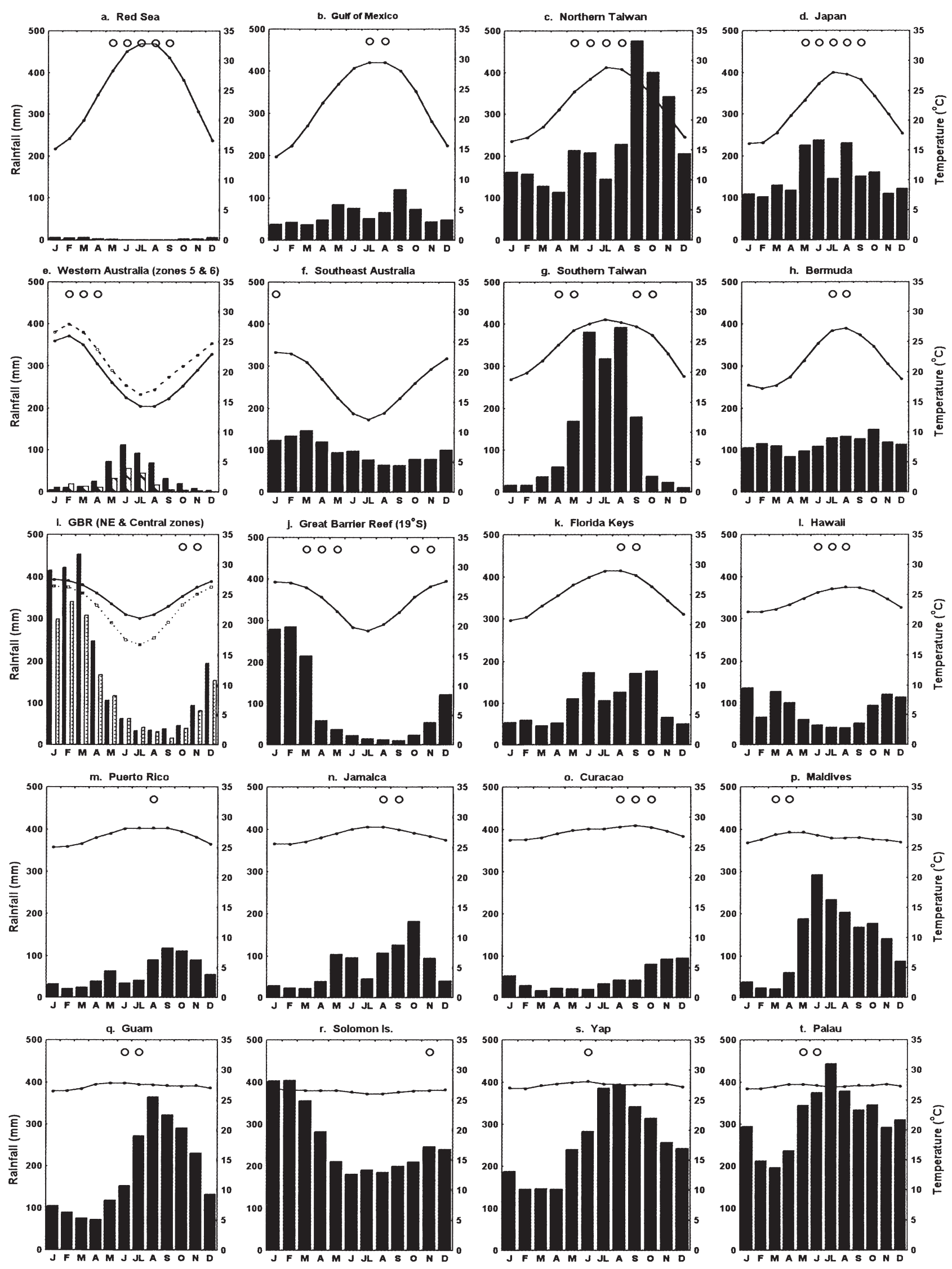
Table 2. Dates of spawning observations for 1994 to 1997 , arranged in order by mo and d. $\mathrm{S}=$ spawning observed, $\mathrm{N}=$ no spawning observed, $\mathrm{n} / \mathrm{o}=$ no observation made, $\mathrm{s}=$ spawning inferred from presence of gametes remaining in samples taken October 4, 1994, ns = no spawning inferred from immature condition of gametes in samples taken on August 25, 1995

\begin{tabular}{|lcccc|}
\hline Date of full moon & \multicolumn{5}{c|}{ Days after the full moon } \\
& 6 & 7 & 8 & 9 \\
\hline Aug 10, 1995 & n/o, ns & n/o, ns & n/o, ns & n/o, ns \\
Aug 18, 1997 & n/o & N & N & n/o \\
Aug 20,1994 & N & N & N & N \\
Aug 28, 1996 & n/o & S & N & N \\
Sep 8, 1995 & N & S & S & N \\
Sep 16, 1997 & n/o & S & S & n/o \\
Sep 19, 1994 & n/o & n/o, s & n/o, s & n/o \\
Sep 26, 1996 & n/o & S & N & n/o \\
& & & & \\
\hline
\end{tabular}

Reef (Fig. 4i,j), and the Solomon Islands (Fig. 4r); at these sites the maximum mean monthly temperature coincides with the rainy season. Additionally, at the sites with the smallest annual temperature ranges (Maldives, Guam, Solomon Islands, Yap and Palau; Fig. 4p-t) spawning occurs just prior to the peak of maximum rainfall.

The timing of spawning (represented by the date of pre-spawning full-moons) in relation to rainfall and temperature at all sites is summarized in Fig. 5. This shows that coral spawning occurs most frequently at times of high seasonal temperature and low rainfall. The log-linear model of best fit included all 2-way interactions as follows: temperature $\times$ rainfall, spawn-

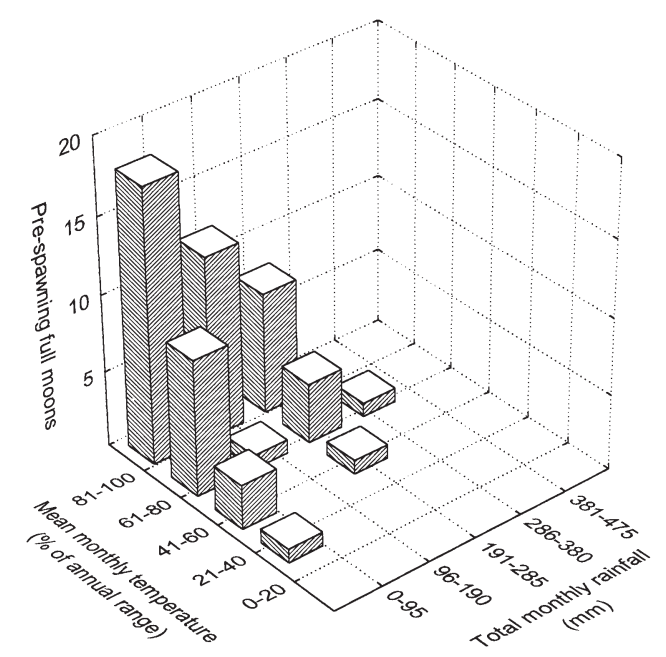

Fig. 5. Time of coral spawning (represented by the date of pre-spawning full-moons) at all locations worldwide in relation to temperature and rainfall ing $\times$ temperature, spawning $\times$ rainfall (chi-squared $=$ 19.81 , df $=16, p=0.23$ ). The chi-squared test is not significant (i.e. the values predicted by the model are not significantly different from the observed values). One can thus conclude that the model is sufficient to explain the frequency of spawning. Tests for partial association (i.e. the difference between the model with and without the respective 2-way interaction being tested) show that both the spawning $\times$ temperature interaction (chi-square difference 61.97, df difference $4, \mathrm{p}<0.0001)$ and the spawning $\times$ rainfall interaction (chi-square difference 13.97, df difference 4, p < 0.01) are significant. Without the spawning $\times$ rainfall interaction the overall model (temperature $\times$ rainfall, spawning $\times$ temperature; chi-squared $=33.07$, $\mathrm{df}=20$, $p=0.03$ ) is insufficient to explain the frequency of spawning (i.e. temperature alone cannot explain spawning). It should be noted that temperature and rainfall have opposite effects on the time of spawning. The likelihood of spawning increases with increasing temperature, but decreases with increasing rainfall.

\section{DISCUSSION}

The duration and timing of gametogenesis and spawning for Montastraea annularis in this study are consistent with those found for $M$. annularis in other parts of the Caribbean (see Table 2, Fig. 4k,m-o; Szmant 1986, 1991, Van Veghel 1994, Van Veghel \& Bak 1994, Steiner 1995, Szmant et al. 1997). Gametogenesis in Jamaican $M$. annularis occurred during a period of increasing water temperature, with spawning taking place 6 to 8 nights following the full moons of August and/or September. The period between the full moon and $M$. annularis spawning appears to be conserved throughout the Caribbean, Gulf of Mexico and Western Atlantic, with spawning occurring 5 to 8 nights post-full moon at all sites where observations have been made (Wyers et al. 1991, Gittings et al. 1992, Van Veghel 1994, Szmant et al. 1997). There does, however, seem to be some geographical variation in the time of year at which spawning occurs, with spawning occurring later in the year at lower latitudes. For example, in 1995 spawning was observed after both the August and September full moons in the Florida Keys (25N ; Szmant et al. 1997), but only after the September full moon in Jamaica $\left(17^{\circ} \mathrm{N}\right)$. Additionally, while spawning has only been observed after the July full moon on the Texas Flower Gardens $\left(27^{\circ} \mathrm{N}\right.$ : Gittings et al. 1992) and in Bermuda (32 ${ }^{\circ} \mathrm{N}$; Wyers et al. 1991), it only occurs after the October full moon in Curacao $\left(12^{\circ} \mathrm{N}\right.$; Van Veghel 1994).

While spawning events at all geographical sites occur only in the warmer half of the year (Fig. 4), there 
is no consistent pattern of spawning with respect to whether temperature is increasing, decreasing, or at its maximum. For example, in Hawaii (Fig. 4l) and Western Australia (Fig. 4e) spawning occurs while temperatures are increasing towards and decreasing from their maximum values, respectively (Simpson 1985, Heyward 1986). Additionally, in the Red Sea (Fig. 4a) spawning occurs not only while temperature is increasing, but also while it is at its maximum value and while it is decreasing (Rinkevich \& Loya 1979, Schlesinger \& Loya 1985). Further in Southern Taiwan (Fig. 4g) and parts of the Great Barrier Reef (Fig. 4j) spawning occurs while temperature is increasing and again while temperature is decreasing, but not during the intervening period when temperature is at its maximum (Harrison et al. 1984, Babcock et al. 1986, Dai et al. 1992, Fan \& Dai 1995). With respect to thermal control of spawning time, the condition may be that spawning does not require temperature to be increasing, decreasing or at its maximal value, but rather to be within some optimal range (with some minimum threshold value below which spawning does not occur).

This wide range of spawning patterns with respect to temperature also suggests that, in addition to providing sufficient time for gonad maturation (Oliver et al. 1988), there may be another ultimate factor underlying the proximate factor of temperature. One possibility is that higher temperatures might also increase the rate of larval development. It is well documented that the rate of embryo development is directly related to temperature (within a range of viable temperatures) for a wide variety of ectotherms including other marine invertebrates and fish with pelagic eggs (e.g. Blaxter 1992, Pennington et al. 1999). The overall energetic cost of development might also be lowered because of the greatly reduced development time. The advantage of reproducing in the warmest months may be the benefits conferred on the coral by having a shorter development time.

In Jamaica spawning occurred most frequently after the September full moon and prior to the period of heaviest rainfall (October; Fig. 3). This is consistent with at least 1 other report of coral spawning: Kenyon (1995), working in Yap, stated that 'local residents are aware of the mass synchronous spawning of corals from 4 to 8 nights after the full moon just before the wet season'. Indeed, when reports on the timing of annual spawning events around the world (Fig. 4) are interpreted in terms of their relationship to rainfall, one finds 2 patterns. Firstly, spawning never occurs when total monthly rainfall is very high (Fig. 4c,g,i,r). Secondly, in locations where there is little year-round variation in temperature (e.g. Maldives, Guam, Solomon Islands, Yap and Palau; Fig. 4p-t), spawning always occurs prior to the peak in annual rainfall. Together, these patterns suggest 2 possible roles for rainfall in the timing of coral spawning. Firstly, that coral spawning is timed to avoid the rainy season, when heavy rainfall would dramatically increase the risk of reproductive failure due to reduced salinity at the water surface; reproductive failure has been shown to be a consequence of reduced salinity in laboratory experiments (Richmond 1993). Secondly, the fact that spawning occurs prior to the peak in annual rainfall at sites with low temperature variation suggests that, although hazardous to coral gametes, the increased rainfall may be beneficial to coral larvae and/or newly recruited polyps. Birkeland (1982) proposed that outbreaks of Acanthaster planci were related to the terrestrial runoff from heavy rains which added nutrients to the water, stimulated phytoplankton blooms, and provided food for A. planci larvae. Most coral species spawn azooxanthellate gametes which then develop into nonfeeding larvae (review in Richmond 1996). These larvae are competent to settle within 18 to $72 \mathrm{~h}$ and usually remain competent for 3 to $4 \mathrm{wk}$ while identifying a suitable location for settlement. Once settled they metamorphose and become able to feed (which they must do heterotrophically until they acquire zooxanthellae). If the coral recruits do not acquire algal symbionts within 2 wk of settling, they risk being overgrown by algae. Studies by Fitt \& Trench (1983) and Schwarz et al. (1999) suggest that zooxanthellae enter through the mouth. If nutrients from rainfall run-off increase not only phytoplankton densities (providing more food for the azooxanthellate polyps), but also the abundance of zooxanthellae in the water column, then the likelihood of coral recruits becoming infected with zooxanthellae (and thus their chance of survival) will be greatly enhanced.

The log-linear analysis of spawning time at 19 geographical locations showed that the effects of temperature and rainfall on spawning time were both significant. The magnitude of the temperature effect was greater than that for rainfall but, on its own, temperature was insufficient to explain the time of spawning. Only when the interaction between rainfall and spawning was incorporated in the model could the timing of spawning be adequately explained. The relationship between temperature and rainfall in relation to spawning can be summarized as follows: the likelihood of spawning events increases with increasing temperature, but decreases with increasing rainfall. During periods of low temperature or high rainfall spawning does not occur, and when the temperature range is small, rainfall is of increased importance in determining spawning time.

Anomalies in the timing of coral spawning (with respect to the traditional interpretation that spawning 
occurs at times of increasing temperature) can be explained when the effects of rainfall are considered along with those of temperature. For example, on the Great Barrier Reef, in the 2 rainfall regions where most spawning studies have been conducted (the northeastern coast and the central coast), maximum rainfall occurs in January and February, as do the maximum temperatures (Lough \& Barnes 1990, Lough 1994). The mass spawning in October and November on the northeastern and central Great Barrier Reef thus occurs prior to the season of heavy rainfall. At this time the Great Barrier Reef lagoon is aperiodically inundated with immense freshwater flood plumes that bathe inshore and inner midshelf reefs with low salinity, often turbid waters (Wolanski 1994, Lough 1998). Additionally, some Tubinaria species on the Great Barrier Reef spawn between March and May (Harrison et al. 1984, Willis et al. 1985), after the rainy season has ended. Further, the bi-annual spawning of 3 Montipora species on the Great Barrier Reef coincides with the period just before and just after the summer rainy season (Stobart et al. 1992). It therefore appears that the time of spawning on the Great Barrier Reef is deflected to the warmest possible temperatures either before or after (or before and after) the period of heavy rainfall in the summer. In contrast to the situation on the Great Barrier Reef is that in western Australia, where spawning occurs in summer (around the time of peak temperatures) and is not impeded by heavy rainfall, since most of the rainfall at these spawning sites occurs in winter (Lough 1998).

In Southern Taiwan, the apparently anomalous spawning of Echinopora lamellosa in September and October, while other species spawn in April or May, can again be explained by considering rainfall in addition to temperature. In southern Taiwan, there is heavy rainfall in summer between June and September (Fan \& Dai 1995) which can decrease salinity and increase turbidity as a result of terrestrial runoff. Spawning in most species occurs in late April or early May, before the rainy season, while spawning in E. lamellosa is delayed until the end of the rainy season (September or October), a time when conditions are again favorable for the survival of coral larvae.

The data presented here, when compared with the existing literature, thus suggest that temperature is not the only environmental variable controlling the annual timing of coral spawning. Rather, the time of coral spawning is controlled by a combination of temperature and rainfall, with spawning occurring in those periods without heavy rainfall in which temperatures are warmest. The ultimate factors underlying temperature and rainfall are proposed here to be enhanced survival and development of gametes, larvae and recruits. Spawning during the period of warmest water probably enhances the rate of larval development, while spawning during periods of low rainfall reduces the risk of catastrophic reproductive failure caused by gametes coming into contact with rain-diluted surface water. Spawning prior to the peak of heavy rainfall, may also increase the food available for newly-settled, azooxanthellate coral polyps, and the chance of such polyps acquiring zooxanthellae. Consequently, colonies that spawn at the highest temperatures outside of, and prior to, periods of heavy rainfall, have offspring that are most likely to survive and develop.

Acknowledgements. We wish to thank Dr Alina Szmant and Miss Catherine Murphy for assistance with the histological techniques used in this study. We also thank Mr Bruce Lauckner (Biometrician at the Caribbean Agricultural Research and Development Institute, Trinidad) for assistance with the statistical analysis. We are especially grateful for the comments made by the anonymous reviewers which considerably improved the manuscript.

\section{LITERATURE CITED}

Babcock RC, Bull GD, Harrison PL, Heyward AJ, Oliver JK, Wallace CC, Willis BL (1986) Synchronous spawning of 105 scleractinian coral species on the Great Barrier Reef. Mar Biol 90:379-394

Babcock RC, Willis BL, Simpson CJ (1994) Mass spawning of corals on a high latitude coral reef. Coral Reefs 13:161-169

Baird AH, Sadler C, Pitt M (2001) Synchronous spawning of Acropora in the Solomon Islands. Coral Reefs 19:286

Birkeland C (1982) Terrestrial runoff as a cause of outbreaks of Acanthaster planci (Echinodermata: Asteroidea). Mar Biol 69:175-185

Blaxter JHS (1992) The effect of temperature on larval fishes Neth J Zool 42:336-357

Dai CF, Soong K, Fan TY (1992) Sexual reproduction of corals in northern and southern Taiwan. Proc 7th Int Coral Reef Symp, Guam 1:448-455

Fan TY, Dai CF (1995) Reproductive ecology of the scleractinian coral Echinopora lamellosa in northern and southern Taiwan. Mar Biol 123:565-572

Fitt WK, Trench RK (1983) Infection of invertebrate hosts with the symbiotic dinoflagellate Symbiodinium microadriaticum. Endocytobio 2:675-681

Giese AC, Pearse JS (1974) Introduction: general principals. In: Geise AC, Pearse JS (eds) Reproduction of marine invertebrates, Vol 1. Academic Press, New York, p 1-49

Gittings SR, Boland GS, Deslarzes KJP, Combs CL, Holland BS, Bright TJ (1992) Mass spawning and reproductive viability of reef corals at the East Flower Garden bank, Northwest Gulf of Mexico. Bull Mar Sci 51:420-428

Guzman HM, Holtz I (1993) The effects of chronic oil-sediment pollution on the reproduction of the Caribbean reef coral Siderastrea siderea. Mar Pollut Bull 26:276-282

Harrison PL (2000) More sex on the reef: recent advances and new horizons for research on sexual reproduction in scleractinian corals. Abstracts 9th Int Coral Reef Symp, Bali A18:99

Harrison PL, Wallace CC (1990) Reproduction, dispersal and recruitment of scleractinian corals. In: Dubinsky Z (ed) Ecosystems of the world, Vol 25, Coral reefs. Elsevier Science Publishers, Amsterdam, p 133-207 
Harrison PL, Babcock RC, Bull GD, Oliver JK, Wallace CC, Willis BL (1984) Mass spawning in tropical reef corals. Science 223:1186-1189

Hayasibara T, Shimoike K, Kimura T, Hosaka S, Heyward A, Harrison P, Kudo K, Omori M (1993) Patterns of coral spawning at Akajima Island, Okinawa, Japan. Mar Ecol Prog Ser 101:253-262

Heyward AJ (1986) Sexual reproduction in five species of the coral Montipora. In: Jokiel PL, Richmond RH, Rogers RA (eds) Coral reef population biology. Hawaii Inst Mar Biol Tech Rep No. 37:170-178

Heyward AJ (1989) Reproductive status of some Guam corals. Micronesica 21:272-274

Heyward A, Yamazato K, Yeemin T, Minei M (1987) Sexual reproduction of corals in Okinawa. Galaxea 6:331-343

Hodgson G (1985) Abundance and distribution of planktonic coral larvae in Kaneohe Bay, Oahu, Hawaii. Mar Ecol Prog Ser 26:61-71

Jamaica Meteorological Office (1943) The rainfall of Jamaica from about 1870 to the end of 1929. 60 year period with maps. Government Printing Office, Kingston

Jamaica Meteorological Service (1973) The climate of Jamaica. Jamaica Meteorological Service publication

Kenyon JC (1995) Latitudinal differences between Palau and Yap in coral reproductive synchrony. Pac Sci 49:156-164

Korringa P (1947) Relations between the moon and periodicity in the breeding of reef animals. Ecol Monogr 17: 347-381

Lough JM (1994) Climate variation and El Niño-Southern Oscillation events on the Great Barrier Reef: 1958-1987. Coral Reefs 13:181-195

Lough JM (1998) Coastal climate of Northwest Australia and comparisons with the Great Barrier Reef: 1960-1992. Coral Reefs 17:351-367

Lough JM, Barnes DJ (1990) Possible relationships between environmental variables and skeletal density in a coral colony from the central Great Barrier reef. J Exp Mar Biol Ecol 134:221-241

Luna JG (1968) Manual of histologic staining methods of the Armed Forces Institute of Pathology, 3rd edn. McGrawHill, New York

Oliver JK, Babcock RC, Harrison PL, Willis BL (1988) Geographical extent of mass coral spawning: clues to ultimate causal factors. Proc 6th Int Coral Reef Symp, Australia 2: 803-810

Pennigton TJ, Tamburri MN, Barry JP (1999) Development, temperature tolerance and settlement preference of embryos and larvae of the articulate brachiopod Laqueus californianus. Biol Bull 196:245-256

Richmond RH (1993) Effects of coastal runoff on coral reproduction. In: Ginsburg RN (ed) Proceedings of the colloquium and forum on global aspects of coral reefs: health, hazards and history. University of Miami, FL, p 360-364

Richmond RH (1996) Reproduction and recruitment in corals: critical links in the persistence of reefs. In: Birkland C (ed) Life and death on coral reefs. Chapman and Hall, New York, p 175-197

Richmond RH, Hunter CL (1990) Reproduction and recruitment of corals: comparisons among the Caribbean, the Tropical Pacific, and the Red Sea. Mar Ecol Prog Ser 60: 185-203

Rinkevich B, Loya Y (1979) The reproduction of the Red Sea coral Stylophora pistillata. II. Synchronization in breeding and seasonality of planula shedding. Mar Ecol Prog Ser 1: $145-152$

Sakai K (1997) Gametogenesis, spawning, and planula brooding by the reef coral Goniastrea aspera (Scleractinia) in Okinawa, Japan. Mar Ecol Prog Ser 151:67-72

Schlesinger Y, Loya Y (1985) Coral community reproductive patterns: Red Sea versus the Great Barrier Reef. Science 228(4507):1333-1335

Schwarz JA, Krupp DA, Weis WM (1999) Late larval development and onset of symbiosis in the scleractinian coral Fungia scutaria. Biol Bull 196:70-79

Sier CJS, Olive PJW (1994) Reproduction and reproductive variability in the coral Pocillopora verrucosa from the Republic of Maldives. Mar Biol 118:713-722

Simpson CJ (1985) Mass spawning of scleractinian corals in the Dampier archipelago and the implications for management of coral reefs in Western Australia. West Aust Dep Conserv Environ Bull 244:35

Simpson CJ, Cary JL, Masini RJ (1993) Destruction of corals and other reef animals by coral spawn slicks on Ningaloo Reef, Western Australia. Coral Reefs 12:185-191

Steiner SCC (1995) Spawning in scleractinian corals from SW Puerto Rico (West Indies). Bull Mar Sci 56:899-902

Stobart B, Babcock RC, Willis BL (1992) Biannual spawning of three species of scleractinian coral from the Great Barrier Reef. Proc 7th Int Coral Reef Symp, Guam 1:494-499

Szmant AM (1986) Reproductive ecology of Caribbean reef corals. Coral Reefs 5:43-54

Szmant AM (1991) Sexual reproduction by the Caribbean reef corals Montastrea annularis and M. cavernosa. Mar Ecol Prog Ser 74:13-25

Szmant AM, Weil E, Miller MW, Colon DE (1997) Hybridization within the species complex of the scleractinian coral Montastraea annularis. Mar Biol 129:561-572

Szmant-Froelich A, Yevich P, Pilson MEQ (1980) Gametogenesis and early development of the temperate coral Astrangia danae (Anthozoa: Scleractinia). Biol Bull 158:257-269

van Veghel MLJ (1994) Reproductive characteristics of the polymorphic Caribbean reef building coral Montastrea annularis. I. Gametogenesis and spawning behavior. Mar Ecol Prog Ser 109:209-219

van Veghel MLJ, Bak RMP (1994) Reproductive characteristics of the polymorphic Caribbean reef building coral Montastrea annularis. III. Reproduction in damaged and regenerating colonies. Mar Ecol Prog Ser 109:229-233

Veron JEN (1995) Corals in space and time. The biogeography and evolution of the Scleractinia. University of New South Wales Press, Sydney, p 321

Willis BL, Babcock RC, Harrison PL, Oliver JK, Wallace CC (1985) Patterns of mass-spawning of corals on the Great Barrier Reef from 1981-1984. Proc 5th Int Coral Reef Congr 4:343-348

Wolanski E (1994) Physical oceanographic processes of the Great Barrier Reef. Marine Science Series. CRC Press, Boca Raton, FL, p 194

Wolanski E, Sarsenski J (1997) Larval dispersion in coral reefs and mangroves. Am Sci 85:236-243

Wyers SC (1985) Sexual reproduction of the coral Diploria strigosa (Scleractinia, faviidae) in Bermuda: research in progress. Proc 5th Int Coral Reef Congr, Tahiti 4:301-306

Wyers SC, Barnes HS, Smith SR (1991) Spawning of hermatypic corals in Bermuda: a pilot study. Hydrobiologia 216/217:109-116 